\title{
Parliamentary Technology
}

\section{Assessment Institutions and Practices}

A Systematic Comparison of 15 Members of the EPTA Network 



\title{
Parliamentary Technology Assessment Institutions and Practices
}

\author{
A Systematic Comparison of 15 Members \\ of the EPTA Network
}

\author{
Michael Nentwich \\ Institute of Technology Assessment [ITA], Vienna
}

\section{Keywords}

parliamentary technology assessment, foresight, parliaments, Austria, Catalonia, Denmark, European Union, Finland, France, Germany, Greece, Netherlands, Norway, Poland, Sweden, Switzerland, United Kingdom, USA, Wallonia

\section{Abstract}

This paper is a systematic comparison of 15 institutions world-wide, which deliver technology assessment (TA) services to their respective parliaments, i.e. perform parliamentary technology assessment (PTA). The fields of comparison are: the role of the parliamentarians (members of parliament) in the TA process; the institutional location inside or outside the parliament; the competence in the parliament for dealing with TA; the type of financing of PTA activities; the mission of the (P)TA institution; its legal status; how topics are selected; whether the topics have a narrower or wider technology notion; what the time frame for the chosen topics is; the working modes; the methods; the number of staff and budget; and finally how they communicate their results. 


\section{Table of Contents}

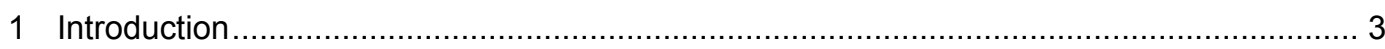

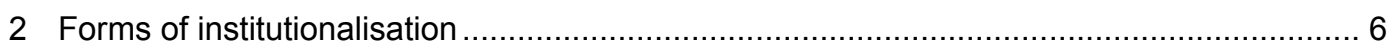

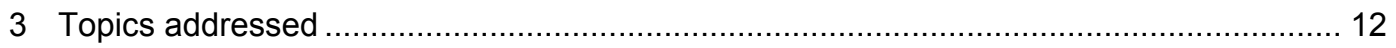

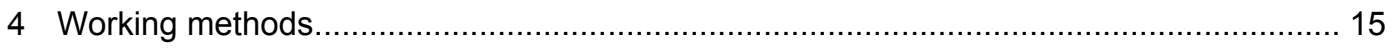

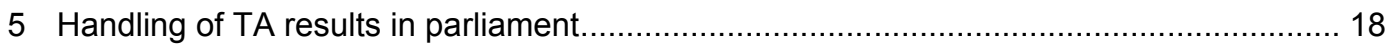

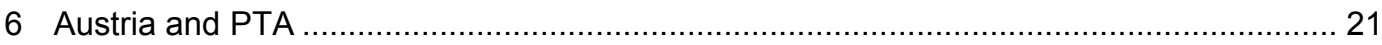

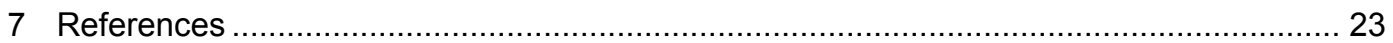

This article is a much extended, translated and updated version of one chapter of the interim report 'Analysis of International Experiences in R\&D Policy Consultation', delivered in German language to the Austrian Parliament in July 2015 by a team consisting of the Institute of Technology Assessment (ITA) of the Austrian Academy of Sciences and the Innovation Systems Department of the Austrian Institute of Technology as part of the feasibility study 'Foresight and Technology Assessment for the Austrian Parliament' (final report published in December 2015: epub.oeaw.ac.at/ita/ita-projektberichte/ITA-AIT-3.pdf). The author thanks his partners in that consortium as well as his colleagues in the EPTA network and at ITA, in particular (in alphabetical order) Georg Aichholzer, Nabajyoti Barkakati, Sergio Bellucci, Christine D'AnnaHuber, Ferran Domínguez Garcia, Reinhard Grünwald, Olli Hietanen, Theo Karapiperis, Helene Limén, Walter Peissl, Melanie Peters, Miroslaw Sobolewski, and Tore Tennøe, for fact checking and feedback. The author is however responsible for all remaining inaccuracies.

\section{MASTHEAD}

Media owner:

Austrian Academy of Sciences (ÖAW)

Legal person under public law (BGBI 569/1921 idF BGBI I 130/2003)

Dr. Ignaz Seipel-Platz 2, A-1010 Vienna

Editor:

Institute of Technology Assessment (ITA)

Strohgasse 45/5, A-1030 Vienna

www.oeaw.ac.at/ita/en/home/

ITA manu:scripts appear at irregular intervals and publish working papers and talks from staff members as well as guests. ITA manu:scripts are exclusively made available to the public via the Internet portal "epub.oeaw":

epub.oeaw.ac.at/ita/ita-manuscript

ITA-manu:script No.: ITA-16-02 (October/2016)

ISSN-online: $1818-6556$

epub.oeaw.ac.at/ita/ita-manuscript/ita_16_02.pdf

(C) 2016 ITA - All rights reserved 


\section{Introduction}

Technology assessment (TA) is a concept of scientific policy consultation that dates back to discussions in the early 1970s in the USA (cf. for instance Bröchler et al. 1999). The starting point was inter-alia the question whether and how much money should be provided by Congress for government sponsored research projects. The complexity of technical developments and the often difficult predictability of the effects led Congress to set up an independent scientific unit - the Office of Technology Assessment (OTA) - whose function was to clarify the possible advantages and disadvantages of a specific innovation.

In the 1980s, this discussion spread to a number of European countries, leading from around 1985 to a series of TA institutions being founded in Europe. At the beginning of the 1990s, these came together to form the European Parliamentary Technology Assessment (EPTA) network. ${ }^{1}$ Currently, 18 institutions in various countries and regions or at the supranational level carrying out TA either in or for their parliaments are members of the EPTA network (see Table 1 below). ${ }^{2}$

The various institutions do not follow a unitary pattern. On the contrary, they are determined by the organisational conditions and political culture in their countries. In paradigmatic terms, however, a distinction can be made between active parliamentary TA committees, offices in parliament (with greater or less involvement of parliamentarians) and independent institutions that work for the parliaments. This international network is gaining in significance, since technological developments and technology policy decisions are increasingly taking place in the international or European context. Because of specific national and regional peculiarities, it is therefore appropriate to exploit this international trend at the level of the individual state parliaments as well.

Europe has recognised the importance of TA: From 2012 to 2015 the European Commission, as part of the Seventh Research Framework Programme under the heading 'Parliaments and Civil Society in Technology Assessment' (PACITA), ${ }^{3}$ funded a major project to establish TA in countries in which there was previously no such institutional structure. Prompted by the variety of activities within the framework of this European initiative, a number of countries are now on the path towards institutionalising TA. The most progress has probably been made by the Belgian region of Wallonia, where currently a legislative proposal to this effect is being discussed in parliament. In Portugal, too, it is becoming apparent that parliament would like technology policy consultations. In other countries such as Bulgaria, Hungary, Czech Republic or Lithuania, TA institutions are also in the course of creation but, in accordance with the national political culture, are expected not to be linked directly to parliament, but more to the government. In addition, outside Europe a number of developments are taking place at the time of writing: For instance, in Japan, a scientific department of the National and Parliamentary Library, the Diet, started carrying out TA studies to inform the parliamentarians and has applied for associate membership in EPTA; and in Mexico and Chile parliamentary units similar to the British POST office have been founded recently.

\footnotetext{
1 eptanetwork.org.

2 Note that, during its history EPTA had two more members: Italy was represented for some time by VAST, the Comitato per la Valutazione delle Scelte Scientifiche e Tecnologiche, and Flanders/Belgium by viWTA/IST, the Institute of Science and Technology. Both organizations have been closed down.

3 pacitaproject.eu.
} 
Table 1: Current EPTA Members

\begin{tabular}{|c|c|c|}
\hline Country & TA institution & Founded \\
\hline \multicolumn{3}{|l|}{ Full members } \\
\hline France & $\begin{array}{l}\text { Office Parlementaire d’Evaluation des Choix Scientifiques et } \\
\text { Technologiques - Parliamentary Office for Evaluation of Scientific } \\
\text { and Technological Options [OPECST], French Parliament }\end{array}$ & 1983 \\
\hline Denmark & Teknologirådet - Danish Board of Technology Foundation [DBT] & 1986 \\
\hline Netherlands & Rathenau Institute of the Royal Netherlands Academy of Sciences & 1986 \\
\hline European Union & $\begin{array}{l}\text { Science and Technology Options Assessment [STOA], } \\
\text { European Parliament }\end{array}$ & 1987 \\
\hline Austria & $\begin{array}{l}\text { Institute of Technology Assessment [ITA] of the Austrian Academy } \\
\text { of Sciences }\end{array}$ & 1988 \\
\hline United Kingdom & $\begin{array}{l}\text { Parliamentary Office of Science and Technology [POST], } \\
\text { British Parliament }\end{array}$ & 1989 \\
\hline Germany & Office of Technology Assessment at the German Bundestag [TAB] & 1990 \\
\hline Switzerland & Centre for Technology Assessment Switzerland [TA-SWISS] & 1991 \\
\hline Finland & Committee for the Future, Finnish Parliament - Tulevaisuusvaliokunta & 1993 \\
\hline Greece & Committee on Technology Assessment, Greek Parliament & 1997 \\
\hline Norway & Teknologirådet - Norwegian Board of Technology [NBT] & 1999 \\
\hline Sweden & Evaluation and Research Secretariat [ERS], Swedish Riksdag & 2007 \\
\hline Catalonia [Spain] & $\begin{array}{l}\text { Consell Assessor del Parlament sobre Ciència i Tecnologia [CAPCIT] } \\
\text { - The Advisory Board of the Parliament of Catalonia for Science and } \\
\text { Technology, Catalan Regional Parliament }\end{array}$ & 2008 \\
\hline \multicolumn{3}{|c|}{ Associated Members } \\
\hline Council of Europe & $\begin{array}{l}\text { Committee on Culture, Science, Education and Media of the } \\
\text { Parliamentary Assembly of the Council of Europe [PACE], Strasbourg }\end{array}$ & [1948] \\
\hline Poland & Bureau of Research [BAS], Polish Parliament & [1991] \\
\hline Russian Federation & Analytical Department of the Council of Federations & [1994] \\
\hline Wallonia [Belgium] & SPIRAL research institute of the University of Liège & [1995] \\
\hline USA & $\begin{array}{l}\text { Center for Science, Technology, and Engineering [CSTE] of the } \\
\text { U.S. Government Accountability Office [GAO] }\end{array}$ & 2002 \\
\hline
\end{tabular}

Legend: The table is ordered according to the year of foundation. The years in brackets indicate that the respective institution has been founded earlier, but the TA function only came later.

In the course of the developments over the last 30 years, it has also become increasingly clear that not only scientific issues but also a wide variety of values, points of view and perspectives should be included in a comprehensive assessment of advantages and disadvantages. Similarly, there is greater awareness of the fact that political decisions can only be implemented in a robust way if they are supported by the citizens. Hence, the participation of representatives of interest groups and a broad public has become a central field of development of TA. At the same time, TA has developed from an initially highly expert-based scientific discipline to become an actor with a moderating function in the field of the governance of technology development. 4

4 At the political level, this learning process and the wording of criteria for good governance are reflected in policy documents such as European Governance. A White Paper (EU Commission 2001), which defined transparency, responsibility, effectiveness and coherence as central action guidelines. 
Beyond institutions that perform parliamentary technology assessment (PTA), there exist many further institutions that pursue TA in one or other form: networks, university chairs and specialised research units. In the German-speaking world (Germany, Switzerland, Austria) in particular, these are organised since 2004 in the Technology Assessment Network (NTA). ${ }^{5}$ In 2014 , such an association has been funded in Poland, too. ${ }^{6}$ This article however focuses on PTA.

The following systematic comparison is empirically based on the study of the relevant literature (Enzing et al. 2012; Ganzevles et al. 2012; van Est et al. 2015; Ganzevles et al. 2014; Delvenne 2011; Decker/Ladikas 2004; Vig/Paschen 2000; Falkner et al. 1994). It also used the comparison table of the EPTA institutions available on the EPTA website ${ }^{7}$, based on Grünwald (2012) and continually updated by the EPTA members, as well as a special issue of the journal 'Aus Politik und Zeitgeschichte'8. Further sources have been the author's own investigations and numerous discussions with the heads of parliamentary TA institutions within the framework of EPTA. Furthermore, the facts have been double-checked by experts from the TA institutions included in the comparison.

The comparison focuses on $15 \mathrm{PTA}^{9}$ institutions, namely those from, in alphabetical order, Catalonia (Spain), Denmark, European Union, Finland, France, Germany, Greece, Netherlands, Norway, Poland, Sweden, Switzerland, United Kingdom, USA, and Wallonia (Belgium). This comparison was first done in a project carried out for the Austrian Parliament with a view to offer alternative models and options for formally institutionalising PTA in Austria. Therefore the Austrian case is not included as such, but treated in a separate section (6), describing the history and status quo as well as the model proposed in the project mentioned.

It starts with the question of how TA for parliaments is given concrete institutional form (section 2), investigates the types of topics that are addressed (section 3), what methods are used (section 4) and, finally, the form in which communication takes place with and between parliamentarians on TA issues (section 5). In the concluding chapter, an overview of the Austrian parliamentary TA development is given against this background (section 6).

5 openta.net/netzwerk-ta.

6 ptot.pl (This link seems defunct when last checked on 17 Oct 2016)

7 eptanetwork.org/index.php/about/comparison-of-epta-members.

8 APuZ 6-7/2014 ,Technik, Folgen, Abschätzung bpb.de/apuz/177757/technik-folgen-abschaetzung.

9 Note that many of the organisations included in this comparison do not exclusively serve as parliamentary TA institutions, but have other duties as well, for instance research or advice to other public institutions like ministries or municipalities (see section 2.5). 


\section{Forms of institutionalisation}

The TA activities of the parliaments are institutionalised in very different ways in the various countries. This section presents the main organisational options as observed internationally in the light of a possible institutionalisation of TA within other parliaments: the role of the parliamentarians (2.1), the location of the TA institution (2.2), the responsibility within parliament (2.3), whether commissioning is handled on a case-by-case basis (2.4), whether the mission is restricted to parliament or wider (2.5) and what the legal status of the TA institution is (2.6).

\subsection{Parliamentarians as addressees or rapporteurs}

Depending on the role of the parliamentarians, the following two basic models can be distinguished:

A1 Parliamentarians are active themselves as rapporteurs and are given assistance in their TA work by a secretariat or scientific staff and/or through outside input.

A2 Work is done for parliamentarians, i.e. the latter commission the TA practitioners who then reply to the questions put (in a TA report or other form).

Case $A 1$ is considerably less common, but prominently implemented in France (OPECST), Finland (Committee for the Future) and in Greece, and previously also in Italy. All other countries have variations of case $A 2$ in differing forms. In Norway and the Netherlands the TA institutions have a general mandate that can be interpreted, rather than answering specific questions put to them by the parliamentarians. Sweden is a mixed case, since there the parliamentarians are involved in the preparation of reports $(A 1)$ but are given very considerable support by the TA institution (A2).

\subsection{Entity within parliament or outside}

Secondly, a distinction can be made according to the location of institutionalisation:

B1 There is a TA department within parliament (as a rule within the parliament administration or in the scientific service) providing TA services (or assisting parliamentarians). The staff of this department are parliamentary employees.

B2 The TA institution is located entirely outside parliament, working (exclusively or project-related) on its instructions and is in some cases funded by parliament.

The classical examples for case B1 are the United Kingdom (Parliamentary Office of Science and Technology - POST) and the European Parliament (Science and Technology Options Assessment - STOA): POST and STOA have roughly a dozen parliamentary employees each. In France, Catalonia, Sweden, Finland and Greece, ${ }^{10}$ and to a certain extent also in Poland, ${ }^{11}$ the corresponding departments are, in contrast, very small (1 to 5 persons).

10 Currently, there is hardly any TA in Greece, with the result that this case cannot be classified.

11 In Poland, only a few employees of the scientific service are occasionally involved with TA activities. 
The Netherlands, Denmark, Norway and Switzerland are typical examples of case B2, although there are large differences here. In the Netherlands and Switzerland, the TA institution is located in the Academy of Sciences. In Denmark, it is a trust, in Norway an independent public institution that is organised as a satellite to the Research Council. ${ }^{12}$ Although these institutions are institutionalised at a relative distance to parliament, there are of course formal and informal contacts, such as the formal programme of a regular exchange of personnel between the Rathenau Institute and the parliamentary administration of the Netherlands States General or the chairing of the TA-SWISS Foundation Council by a former parliamentarian, the Council having the explicit task to take care of the external relations of TA-SWISS, including those with Parliament.

The German TAB occupies an intermediate position. It is located outside parliament, and its eight employees are not part of the parliamentary administration but in formal terms are employees of the research institution (ITAS Karlsruhe), who operates TAB. However, the TAB works exclusively for the Bundestag and is accordingly entirely financed by it.

\subsection{Responsibility within parliament}

In most parliaments that pursue TA or are advised by TA institutions, there is a committee or a group of parliamentarians that acts as contact point to the consultants. There are the following cases:

C1 One single committee or panel of members of parliament with explicit responsibility

C2 A body composed partly of parliamentarians and partly of external personnel

C3 No direct responsibility within parliament for the TA institution

A few examples of case C1 (parliamentary committee):

- In Germany, this is the 'Committee for Education, Research and Technology Assessment'. All parliamentary parties represented in the Bundestag and hence in this committee have a spokesperson for technology assessment, who form the group of 'TA rapporteurs'. This group is the direct contact partner for TAB and, internally, for all parliamentarians, including from other committees (e.g. for environment, economy, health etc.) that have questions for TAB. They prepare all decisions. The main function of the committee is the decision on the TAB working programme, the discussion and acceptance of the reports and the inclusion of the findings in parliamentary work. The committee's activity is supported by its committee secretary (the TA agenda is handled by one person from this secretariat).

- The European Parliament has set up the 'Science and Technology Options Assessment' $\left(\mathrm{STOA}^{13}\right)$ Panel, comprising $25 \mathrm{MEPs}$ appointed by nine parliamentary committees. ${ }^{14}$ The STOA Panel elects a four-member STOA Bureau (including ex-officio the European Parliament's Vice-President responsible for STOA) from amongst its members to coordinate the activities and prepare the meetings. Each project is formally led on behalf of the Panel by one MEP (so-called 'Lead Panel Member'), but direct communication with the TA institution carrying out the project is via the STOA secretariat, a parliamentary administrative body.

12 TA-SWISS was also initially a part of the Swiss Scientific Council.

13 Note that the STOA secretariat is now part of the Scientific Foresight Unit, belonging to Directorate for Impact Assessment and European Added Value of the Directorate-General for Parliamentary Research Services (EPRS).

14 Industry, Research and Energy; Employment and Social Affairs; Environment, Public Health and Food Safety; Internal Market and Consumer Protection; Transport and Tourism; Agriculture. 
- In France, there is a body composed of members delegated by both chambers of parliament (National Assembly and Senate), the Office Parlementaire d'Evaluation des Choix Scientifiques et Technologiques (OPECST) with 36 members (18 from each of the two chambers), the chair and deputy chair rotating between the chambers on a triannual basis. The parliamentarians are assisted by a small secretariat. In addition, OPECST has a 24-person scientific advisory board.

- The Finnish Committee for the Future consists of 17 parliamentarians from all parliamentary parties who discuss questions of the future and issue requests for expertises to the secretariat.

- In Greece, the Permanent Committee for Technology Assessment consists of 25 parliamentarians.

Examples of case $\mathrm{C} 2$ (mixed bodies):

- In Catalonia, the 21-person CAPCIT is a mixed body comprising nine parliamentarians and twelve representatives of the main scientific institutions, including the Academy of Sciences. The committee is assisted by a secretariat comprising one person.

- In the United Kingdom, POST collaborates with the POST Board, which comprises 14 members of the two houses (House of Commons and House of Lords), and roughly reflects the relative strengths of the parliamentary parties; in addition, the members of the POST Board include leading representatives of the science and technology community and ex officio the POST Director, and further persons from the parliamentary administration.

Examples of case $C 3$ (no direct responsibility within parliament):

- In Switzerland, there is no separate TA committee in parliament, but instead TA issues are addressed to the relevant committee in each case. The roughly 15-person TA-SWISS Steering Committee (Leitungsausschuss) consists of persons with very different institutional and subject backgrounds, who deal with the projects. It was chaired by a former member of the National Assembly and from October 2016 it is chaired by a former energy minister. The new Foundation Council (Stiftungsrat), responsible for strategic issues and external relations will be chaired by a former president of the Council of States (Ständerat), the smaller chamber of the Parliament. Thus he constitutes the link to parliament - an arrangement intended to ensure the maximum of independence, including from the political level within parliament itself.

- In the Swedish Riksdag there is no separate committee responsible for TA, since it is assumed that the topics of all TA activities are per se located across a number of committees. Accordingly, for each project a reference group is set up by the leading committee comprising representatives of different parliamentary parties (often one representative from each party), which determines the concrete form of the questions to be examined and accompanies the project. As in Sweden, there is no formal committee in the Netherlands or Norway. Communication takes place on a topic-by-topic basis with various committees and in special hearings.

- The Danish DBT, following its re-foundation in 2012, has currently no formal connections with parliament, although almost all parliamentary parties are interested in re-establishing the close relationships with the parliamentary scientific committee, and work is being actively carried out to this end.

There are surprisingly large differences in terms of the frequency with which these various parliamentary committees meet, in particular as compared with the frequency within the Austrian National Assembly. Thus the committees in Germany meet roughly three times a month for half a day, in Finland and Sweden twice a week for one to three hours, and in the European Parliament 10-12 times a year for 90 minutes (not counting numerous workshops and other information and dialogue events with the active participation of MEPs). 


\subsection{Case-by-case funding/commissioning or framework contract}

When contracts for TA studies are awarded to third parties, the following distinctions can be made:

D1 A new contract is issued from topic to topic (where appropriate with invitation to tender) and is not as a matter of principle always conducted by the same TA institution.

D2 A framework contract is concluded with one or more scientific institutions with TA expertise, these then always being involved for a particular period.

D3 Parliament does not award contracts in the narrower sense, but the mission of the publicly funded TA institution lays down that parliament is to be informed about the results of current studies.

Case D1 is implemented in Finland for instance, where individual studies are awarded externally on a case-by-case basis. The Catalan Parliament does not award contracts in the narrower sense, but the mission and position of the scientific institutions present in CAPCIT lay down that these institutions are willing to inform the parliament; the external experts commissioned, however, are not funded by the parliament.

Case D2 is implemented at institutional level in Germany, where a public invitation to tender leads to one TA Institute (or a consortium) being contracted with the operation of TAB by the Bundestag for a period of five years at a time.

In two instances, cases $D 1$ and $D 2$ are combined, in different forms tough: First, the Committee for the Future also has a permanent agreement with the Finland Futures Research Centre, one member of which is even the vice-Committee Counsellor. So the Finnish case falls both in category $D 1$ and $D 2$. Second, the case of the European Parliament also combines both alternatives at project level: the STOA Secretariat awards framework contracts for specific topic areas (case D2), while the institutions or consortiums with framework contracts are then invited to bid for a specific topic (case D1). A number of EPTA members have formed the European TA Group (ETAG), and this group has currently such a framework contract with STOA for a number of topic areas ${ }^{15}$, along with a group of other framework contractors for each of these areas.

In Norway, the Netherlands and Switzerland, and previously also in Denmark, the TA institutions are financed by the government and report to parliament (case D3).

15 See itas.kit.edu/english/etag.php. 


\subsection{Mission: Focus on parliament or open contracting structure}

While units within parliament as a rule work exclusively for the parliament, ${ }^{16}$ external TA units can also act for other clients:

E1 The (external) TA institution works exclusively for the parliament.

E2 The institution can also take on contracts for other bodies, such as government institutions (ministries), or can pursue parallel research operations, which are financed for instance via research funds or other basic funding.

The classical example of case $E 1$ is the German TAB, which is not placed inside and not part of the Bundestag. Obviously the secretariats or units inside the respective parliament, like the British POST, the staff serving the French OPECST, the Greek Committee on TA, the Swedish ERS, the Polish BAS, the STOA Secretariat, and last but not least the secretariat of the Finish Committee for the Future are all internal TA institutions serving its parliament only. Most other TA institutions come under case E2. In a number of cases, projects directly for parliament are even the exception, either permanently (e.g. in Switzerland) or in specific phases (e.g. in Denmark, the Netherlands). The Dutch Rathenau Institute is currently the only parliamentary TA institution that is involved in scientific publications alongside political consulting activity to a significant extent. ${ }^{17}$

\subsection{Legal status}

The TA institutions working for the various parliaments have been created in a variety of ways and are organised in legal terms in a variety of forms. The following possibilities exist:

F1 Parliamentary resolution (law, amendment of the standing orders, decision of the parliamentary presidency, etc.)

F2 Established by a ministry (decree) or another public body and a possible subsequent (formal or informal) attachment to parliament

F3 Foundation, possibly initiated by parliamentarians, and subsequently attached to parliament

Finland, Switzerland and France are examples of case F1, where the TA institution resp. the Committee was set up by law or in the form of the standing orders. In Germany, this was done through a resolution by the Bundestag, in Catalonia by a resolution of the Bureau of the Parliament (literally an agreement of the Bureau), which must be renewed at the beginning of each legislative period. In the European Parliament, STOA was likewise created through a decision of the Parliament's Bureau implementing a parliamentary resolution, similar to the cases of Greece and Poland.

Case F2 is represented by the Netherlands, where the TA institution was set up under the aegis of the Academy of Sciences by a decree of the Ministry for Education, Culture and Science. In Norway, the NBT was established by royal decree in 1999 , following an initiative by the Norwegian Parliament (Stortinget).

16 The legislative bill currently being discussed by the Walloon Parliament provides that the proposed TA unit is to be located within parliament but should also work for the government.

17 See, however, section 6 on the Austrian case. 
The Danish TA institution was most recently reorganised as a foundation (case F3), the initiative only coming indirectly from parliamentarians. ${ }^{18}$ The predecessor institution of the same name was an independent public institution founded and financed by the Ministry of Science (case F2). The first TA institution in United Kingdom was also originally organised as a foundation and taken over by parliament after a few years. As from October 2016, TA-SWISS is also a foundation (but will continue to remain within the Swiss Academies of Science, which are the funders and are represented in the Foundation Council).

18 The governing parliamentary parties reduced the part of the science budget intended for the DBT; the creation of a foundation was the solution so as to maintain the DBT, from then on exclusively financed by third-party funds. 


\section{Topics addressed}

Technology developments are a wide field and so are the topics potentially addressed by the TA institutions. The processes for identifying the topics differ (3.1), the reference to technology may be more or less close (3.2) and the time horizons of the issues dealt with vary (3.3).

\subsection{Identifying topics}

A central aspect for the efficacy of the support for parliament is the procedure for identifying topics. The TA institution can select its topics more or less independently:

G1 The TA institution (or its board) conducts regular or continuous topic monitoring activities and begins projects under its own initiative, communicating the results to the parliamentarians.

G2 The thematic programme (the concrete projects and their prioritisation) is agreed between parliament and the TA institution and laid down at regular intervals.

In case G2, various alternatives have been implemented that occasionally occur in combination:

a. There is one single committee or panel of members of parliament responsible that adopts decisions on the programme to be handled.

b. Various topic-based committees or an entire chamber (or majority) of parliament can determine the topics.

c. A parliamentary steering group acts as clearing office for proposals by parliamentarians, irrespective of the committee they belong to.

d. The topics for the TA institution are determined by the parliamentary administration.

e. Determination of topics on the basis of substantive legislation.

f. Enquiries from individual parliamentarians or by thematic ad-hoc groups.

Typical examples of case G1 are Norway, Finland, the Netherlands, Switzerland and the United Kingdom. In the Norwegian NBT, the Board decides autonomously at two-year intervals about the topics to be handled by the NBT Secretariat, with thematic flexibility being maintained for current issues. The Norwegian Parliament only plays an indirect role in determining topics, namely by virtue of its being the main addressee, i.e. the NBT attempts to handle only topics of political relevance which will also be of interest to parliament. The British POST conducts monitoring on a regular basis, and at the beginning of each legislative period the expected important topics are published in a separate POST Note; this monitoring process also includes proposals from parliamentarians, the scientific community, business and civil society; ultimately, the POST board decides at quarterly meetings on the studies for the coming period. In Switzerland, too, topics are determined on the basis of a continuous monitoring of technological and social developments, with proposals from external experts and the Steering Committee also being included, the latter also making the decision on the programme. When identifying topics the Dutch Rathenau Institute is advised by a separate Programme Advisory Board that comprises members of the scientific community, the media, politics and business. The decisions are made by the Institute Board, which lays down the two-year working programme according to specific criteria, with scope remaining for current developments - as in Norway. In the determination of this working programme, an opinion is obtained from parliament and a comment 
from the Ministry of Science. The Finnish Committee for the Future can determine its topics itself and is explicitly made completely independent (it consists however of politicians).

The US GAO also has the possibility of determining its topics itself, namely by order of the GAO management to the TA Department itself. The Scientific Service of the Polish Parliament can also act at its own initiative if it is apparent that a topic will be of relevance for future parliamentary work. The 24-person Scientific Council of the French OPECST also has the function of identifying the most important topics and also takes up corresponding signals from the scientific community, however, formal topic selection takes place along different paths (see below).

The classical example of case $G 2$ is Germany, where the project topics are formally awarded by the committee responsible (variant a), but prepared by the 'Rapporteur Group' (consisting of the TA spokespersons of all parliamentary parties) in consultation with the head of the TAB. Topic proposals can be submitted by all committees, parliamentary parties, working parties and even by individual parliamentarians (variant $c$ and $f$ ). The STOA Panel of the European Parliament is composed of representatives of different specialised committees (variant a).

The French OPECST can take up a topic in three different ways: firstly, on the instructions of the parliamentary administration (variant $d$ ), either at the latter's own initiative or at the initiative of the leader of one of the parliamentary parties (variant $f$ ) or on the basis of a vote by at least 60 parliamentarians or 40 senators. The second method is a vote by a thematic committee (variant $b$ ). Since OPECST cannot determine a topic itself, it is therefore reliant on other parliamentarians (who are not OPECST members) being persuaded informally to make a topic initiative. A third form, established nowhere else, is the adoption of a topic by virtue of statutory regulations in specific precisely defined cases (variant $e$ ).

In Sweden, the precise question to be examined is determined following a basic decision to conduct a study adopted in an interactive process between the ERS and an ad hoc group comprising parliamentarians with an interest in the topic (variant $f$ ). The European Parliament's STOA Panel also receives suggestions from thematic committees and from its own members; however, the final decision is taken by the panel itself (variant a), taking a number of criteria into account (e.g. parliamentary relevance, strategic significance etc.). Likewise, the CAPCIT in Catalonia alone decides what topics are to be addressed; topic proposals are usually submitted by the scientific members of the CAPCIT.

The project work of the TA Department of the US GAO is as a rule triggered by a committee submitting an enquiry (variant $b$ ), although limited resources mean that not every enquiry can be answered immediately; as for specific topics, GAO is led by the principle that they can be selected by both the majority and the minority (of both Houses). However, there is also the possibility of individual Senators and Congressmen submitting an enquiry (variant $f$ ). In addition, the TA unit can also act autonomously (see above, case G1). Similarly, the Polish BAS can undertake studies on request of committees (variant $b$ ), but most of the TA-related work is initiated internally by the BAS team.

\subsection{Technology reference}

While most projects of the parliamentary TA institutions revolve around technologies, such as security technologies, energy issues, genetic engineering, nano-technologies or the Internet, technology assessment is not interpreted everywhere in a narrower sense as focusing solely on technological issues, and in a number of cases interdisciplinary topics that only have a relatively small reference to technology are addressed under this label or in this connection. In 
particular, wherever foresight plays a greater role (such as in Denmark and Finland), science is addressed along with technology (European Parliament, Netherlands) or where technology assessment generally is not an explicit topic (such as in the Netherlands), the reference to technology can at times also be small.

Examples of topics that are not primarily technological can be found in the common project list of the EPTA institutions: ${ }^{19}$ The management of epidemics, lessons to be learnt from the eruption of the Icelandic volcano or the relationship between health and environmental factors (France), science metrics or discovery of the scalar boson (European Parliament), deterioration of the quality of farmland, juvenile law or Alzheimer's (United Kingdom), relationships to Russia, welfare society or the education system (Finland), biodiversity, science in dialogue or obesity (Denmark), academic careers, the rise of Asia or the reliability of scientific institutions (Netherlands), tourism trends, trends in industrial work or biodiversity (Germany).

Finally, it should be pointed out that alongside classical TA there is also the field of health technology assessment (HTA), which is institutionalised separately in most countries, ${ }^{20}$ there of course being thematic overlaps.

\subsection{Thematic time horizon}

The types of TA activities conducted by and for parliaments differ also according to time horizon:
$\mathrm{H} 1$ Long-term perspectives
$\mathrm{H} 2$ Medium term
H3 Short-term decision-making aids

TA projects can have very long-term perspectives as their subject matter (case H1), such as climate change, biodiversity, demographic change (ageing society), sustainability or the future of energy (so-called Grand Challenges). Often, the subject of the analysis is a technology whose implementation is still in the distant future, such as synthetic biology, human cloning, geo-engineering or human enhancement.

While most TA studies, in contrast, tend to have a medium-term time horizon and address technological and social trends that will become apparent within the next 3 to 5 years (case $\mathrm{H} 2$ ), TA institutions may also conduct projects whose time horizon is very short and that are aimed at accompanying, analysing or evaluating current developments (case H3). Examples of this are studies concerning pending decisions on the storage of nuclear waste, the decision on the siting of a $380 \mathrm{kV}$ power line, on consulting for the direction of research programmes, on the evaluation of participatory processes or on the need for regulation of e-cigarettes.

These different time horizons also lead to different methodological approaches. Thus it is obvious that foresight methods play a greater role with longer perspectives (see below 4.2).

19 eptanetwork.org/index.php/database/projects.

20 Thus also in Austria: the Ludwig Boltzmann Institute for Health Technology Assessment (LBI-HTA), hta.lbg.ac.at, is the offspring of a former working party at the Institute for Technology Assessment (ITA). 


\section{Working methods}

TA institutions not only differ when it comes to their formal set-up and what topics they deal with in what manner, but also when it comes to their working methods. Significant changes may be observed when it comes to who actually performs TA (4.1), what methods are usually applied (4.2) and how much budget and staff is attributed (4.3).

\section{1 'TA secretariat' or 'in-house' TA}

The TA institution (external or internal, consisting of parliamentarians or not) has either

I1 a multidisciplinary team of TA experts and conducts the TA studies itself, or

12 it outsources the studies (in whole or in part), for instance to experts at universities or other TA institutions.

Case $I 1$ is for instance implemented in Norway, Denmark, United Kingdom, and in the Netherlands. Where necessary, external experts are of course also included in the projects; and projects may be carried out generally in cooperation with other institutions. An example of the latter is the cooperation within the framework of the European TA Group (ETAG), which conducts studies for STOA.

The European Parliament, Germany, Switzerland and Catalonia fall under case I2. In Germany, as a rule, for each topic an invitation to tender is published for one or more pieces of expertise that are then combined with research by the TAB to create a TA report. In the case of Switzerland, all expertise is also awarded externally, but the TA-SWISS team has a high level of responsibility for the determination of TA issues and process competence in the conduct of participatory events; the TA-SWISS external contractors are supported or even coached by the TA experts in a number of sessions. The studies for the Catalan CAPCIT are likewise always outsourced (and without additional financing by parliament) to universities and other research institutions (irrespective of whether they are represented in CAPCIT or not); when a TA report is done by the Catalan Foundation for Research and Innovation (FCRi) they use an external referee to review the text; when a CAPCIT bulletin is done by the Catalan Studies Institute (IEC) their three members/representatives review the text, without any significant editing given the lack of a correspondingly equipped TA secretariat.

There are also mixed cases: While most of the work of the Committee for the Future in Finland is carried out via expert hearings and seminars in the Parliament, expertise is also outsourced, but to a considerably smaller extent. There is a number of external research institutions advising the Parliament on its request, either with studies or in hearings and seminars. The French OPECST also has a budget for involving external experts, but does so rarely, as is the case with the TA Department of the US GAO. The Polish BAS also applies a mixed internal/external working method: Some of the studies are carried out by the BAS team, but many topics that require more in-depth knowledge are outsourced to external experts (mostly academic institutions). While the European Parliament's STOA outsources most of the work carried out for the STOA Panel, it also prepares techno-scientific trends reports and so-called 'What if' publications drawing exclusively upon in-house expertise. 


\subsection{Methods applied}

The various TA institutions also differ with respect to the methods used:

J1 Expert TA: literature study, Delphi, focus groups, hearings, expert seminars, etc.

J2 Participatory procedures: involvement

a. of interest group representatives (stakeholders)

b. of laypersons (citizens)

J3 Foresight: Delphi, scenario workshops, etc.

Some institutions typically work with only or mainly one method: the French OPECST, the Polish BAS, and the British POST are typical representatives of the expert TA (case J1), while most projects of the Dutch Rathenau Institute and the Danish DBT are of a participatory nature (case J2). Other TA institutions have a mixed method portfolio, such as TA-SWISS or NBT with a majority of expert TA and many participatory procedures.

The Finnish Committee for the Future has a particularly mixed methods' bag, as it is both expert-oriented both via hearings and commissioned studies (case J1), but also involves stakeholders in hearings and lets participate citizens (case J2); finally it specialises in foresight activities in cooperation with the Finland Futures Research Centre (case J3). Usually hearings and seminars precede the decision to carry out an in-depth study.

The methods to be used can be laid down in the TA institution's foundation document or develop informally in practice. Thus for instance it is the explicit mission of the Norwegian NBT and the Dutch Rathenau Institute to encourage public debate in technology issues and therefore to include laypersons. Participatory methods are also explicitly mentioned in the performance agreement which forms the basis for TA-SWISS's activity. Generally, it can be seen that the TA institutions that are located very closely or even within parliament as a rule use participatory methods less frequently or even not at all.

However, even the German TAB, renowned for its expert-focused working methods, has recently addressed citizen participation methods. The TAB's range of functions was extended by participatory elements in 2013. The new working field is called 'Discourse analysis and dialogue with social actors'. Its aim is to establish a dialogue forum for society and politics to discuss and assess scientific technical developments (stakeholder panel, case 2/b).

Finally, the different time horizons for topics (see 3.3) also lead to methodological differences. Foresight methods (case J3) obviously play a particular role with longer perspectives, in particular in dealing with Grand Challenges. The Danish DBT is a case in point here (see for instance its WWViews series), as is the Finnish Committee for the Future. Since 2014 the European Parliament's STOA has been putting increased emphasis on foresight work, based on a scientific foresight methodology developed internally and launching the first foresight studies (first completed in June 2016). 


\subsection{Staffing and budget}

The differences in working methods and functions mean that the TA institutions differ in terms of staffing and budget (see Table 2). With some TA institutions, this basic budget is supplemented to varying degrees by third-party funding (from research funds, from the EU Research Framework Programmes, governments etc.), the institutions located directly in or at parliament as a rule not having access to this source of funding. ${ }^{21}$

Table 2: Size and budget of selected TA institutions

\begin{tabular}{llcc}
\hline Country & TA institution & Staff & Basic budget per annum [TEUR] \\
\hline Denmark & DBT & $34^{22}$ & 1.200 \\
European Union & STOA & 12 & 650 \\
Germany & TAB & 8 & 2.000 \\
Netherlands & Rathenau & $44^{23}$ & 4.400 \\
Norway & NBT & 8 & 1.100 \\
Switzerland & TA-SWISS & 8 & 1.700 \\
United Kingdom & POST & 11 & 700 \\
\hline
\end{tabular}

The secretariats inside the Parliament supporting the parliamentarians, such as in France, Finland, Sweden or Greece, are usually rather small, from one to five staff, with only small budgets for soliciting studies to external contractors.

21 The legislative proposal for the establishment of a TA unit currently being discussed in the Walloon parliament includes for the first time a specific provision on this point explicitly allowing financing by third parties and hence also by the government.

22 The DBT is not exclusively focussing on TA in a narrow sense, for instance if it carries out dialogue meetings for a municipality; so not all of the $30+$ staff members carry out TA projects.

23 The Rathenau Institute has two departments: Science Assessment and TA; the TA department has around 14 full-time employees. 


\section{Handling of TA results in parliament}

A final distinction between the various types of TA institutions internationally can be made with regard to how the TA results are communicated in the parliament, whether in written form (5.1) or orally (5.2).

\subsection{Written communication}

Alongside various types of events at which TA results are also discussed (see 5.2 below), they are in any event also presented to the parliamentarians in writing. The following text types have proved to be successful at international level:
L1 Policy briefs
L2 Reports
L3 Executive summaries
L4 Presentation documents
L5 Scientific Articles

Policy briefs (L1): These dossiers are very short (between one and a maximum of six pages), worded in a non-scientific language and in terms of content tailored to be politically relevant. Many parliamentary TA institutions make use of such policy briefs, ${ }^{24}$ the most prominent example being the British (four-page) POST Notes, of which there are now far over 500. Similar dossiers are also drawn up for the European, the Catalan, the Danish, the Norwegian, the French, the Dutch, the Polish and most recently also for the German parliament. The shortest are the one page briefs that accompany reports produced by the GAO for the US Congress.

Reports (L2): As a rule ${ }^{25}$ longer project reports form the basis for the above-mentioned policy briefs. In the case of Germany, the TAB reports are up to 250 pages long and are almost always published as Bundestag publications, in some cases also as a book (as is also the case in Switzerland); similarly thick reports are also produced by the French OPECST. In Catalonia, in contrast, the reports are not published but instead are distributed amongst parliamentarians; however, the authors (in the universities etc.) are entitled to publish their reports themselves. In order to provide better access to these reports for parliamentarians and their staff, the graphic design of these reports is often sophisticated (for instance using charts and marginal notes). Also the Dutch Rathenau Institute, the Finnish Committee for the Future, the Norwegian NBT and the European Parliament's STOA publish their reports.

Executive summaries (L3), i.e. short summaries (as a rule occupying several pages) of the main results, including options for action and recommendations (see below), are a typical component of the reports, which are often published separately (and where necessary also translated); this is the case in Switzerland, for instance (where hitherto there is no separate series of policy briefs) and, occasionally, in France and the European Parliament.

24 See the EPTA policy brief database: eptanetwork.org/index.php/database/policy-briefs-reports.

25 Even the British POST sometimes but by no means always produces longer reports, but as a rule only the Notes, i.e. short policy briefs. 
Presentation documents (L4): On the occasion of an oral presentation of the TA report results in parliament (see below, 5.2), as a rule the presentation documents (e.g. PowerPoint transparencies) are also distributed as handouts.

Scientific articles (L5) are, in contrast, as a rule not regarded as an appropriate text type for the communication between research and politics. Nevertheless, there are a number of TA institutions that are more strongly anchored within the scientific community, with some also being evaluated according to scientific criteria, with the result that scientific publications in part constitute a major element of the publications (for instance for the operator of the German TAB, the ITAS in Karlsruhe).

Leaving aside the written form, the study results communicated by the TA institutions to parliaments also differ in terms of content:

\section{M1 Options for action \\ M2 Recommendations \\ M3 Motions}

Options for action (M1): A number of TA institutions, after analysing the factual situation, restrict themselves to a list of options, often on the basis of scenarios, together with the possible effects. TA thus extends the possibilities and scope for action. This is for instance explicitly the case for the British POST, TA-SWISS, the German TAB and the European Parliament's STOA.

Recommendations (M2): Occasionally, after consideration of the information available and the listing of the options, the TA institutions also make recommendations for action, i.e. the scope of possibilities is evaluated and thus restricted again. In the case of institutions located very close to or within parliament, this alternative is unusual or even explicitly prohibited, since recommendations are regarded as influencing political processes. In contrast, the Norwegian NBT, for instance, is instructed to give parliament concrete recommendations. The Danish DBT as a rule issues recommendations.

Motions (M3): The Finish Committee for the Future issues motions from the Parliament to the Government, and Government has to do what the Parliament says. Similarly, the French OPECST does not only give recommendations for action but as a rule also proposes legislative initiatives on the basis of the reports.

\subsection{Oral presentation and discussion}

In the various parliaments, different forms of discursive processing of the consulting input developed by TA have developed:
N1 Hearing or workshop
N2 Reporting in committee
N3 Bilateral meetings
N4 Special events

Hearing (N1): A formal hearing or workshop in parliament is organised on the topic of the TA study, to which not only the authors of the study but also further experts and/or stakeholders are invited, who each present to the parliamentarians a brief oral (possibly also simultaneously written) input from their perspective, which is then discussed by the parliamentarians. This takes place for instance in the Dutch and the Danish parliaments. In some cases, such events 
experiment with rules specifically drawn up for the type of intervention by the experts and the parliamentarians, such as a strict two-minute limit on speaking time so that as many participants as possible can have their say, thus increasing the chances of a lively debate.

Reporting in the thematically responsible committee (N2): The TA report is called up as one (amongst many) items on the agenda, one or more TA experts briefly present the report previously submitted in writing and are available for questions from the parliamentarians. This is followed by a discussion amongst the parliamentarians. Examples of this are Germany, the European Parliament, Switzerland and Norway. In the European Parliament, interim and final outcomes of studies are also presented during meetings of the STOA Panel. In Norway, MPs from all parties have formed a "Tekno group" dedicated to the discussion of emerging technologies with a potentially great societal impact. The NBT acts as the secretariat for the group, organises meetings with expert presentations, and produces policy briefs for every event. Hearings in the Committee for the Future are a very important tool in Finland, involving 150-200 experts a year.

Bilateral meetings with individual parliamentarians (or parliamentary party groups/fractions) (N3): The TA experts offer to discuss with the parliamentarians (possibly also only on the telephone) in order to explain the TA results. While such meetings are (additionally) usual in all countries, it is the standard approach in Switzerland.

TA special events (N4): Occasionally, specific presentation events, with or without the involvement of other experts and/or stakeholders, are held within or outside parliament by the TA institution, to which the parliamentarians involved in the matter are invited. TA-SWISS regularly organises public events with invited experts and stakeholders to present the results of the study. The British POST frequently issues invitations to moderated breakfast presentations (i.e. at the start of the parliamentary day), with a handful of external experts providing brief inputs on the topic and members of parliament having the opportunity to submit questions and discuss in an informal setting. In Sweden, open debates are held in parliament on a topic to which parliamentarians as well as external experts, stakeholders and the media are invited. The Dutch Rathenau Institute also organises frequent public (discussion) events (public debates, talk shows, forum discussions etc.) directed not only at politicians but also a much broader public. In Germany, public committee sessions are held on special topics. Also the Finnish Committee for the Future holds special expert seminars or invites government members or officials. In the European Parliament, STOA also organises ad-hoc workshops not directly linked to studies, often in cooperation with external stakeholders, making sure to include, in a balanced way, the widest range of viewpoints and focusing the debate on options, rather than a specific approach or solution. 


\section{Austria and PTA}

As early as the 1980s, Austria also became one of the first countries with its own TA institution (see Table 1 above). In 1985, a working party was set up at an existing Institute of the Austrian Academy of Sciences (ÖAW), which was upgraded in 1988 to become a temporary Research Unit for Technology Assessment (TAU). As part of the Academy of Sciences the TA unit has devoted itself to scientific TA, therefore publications in academic journals count as an important evaluation criterion. At the same time, the TA unit always had a mission to inform and advice politics and society with regard to topics in science and technology.

In 1990, the TAU conducted the study on the ' $380 \mathrm{kV}$ powerline Kaprun/Zell am Ziller' for the parliamentary Petition Committee, and in 1992 served as scientific secretariat for the parliamentary commission of enquiry on the topic of 'genetic technology'. In 1993, the TAU organised the 'Parliamentary TA Symposium' with foreign and Austrian parliamentarians, and in the same year became an associated member of the EPTA. In 1994, the TAU became the permanent Institute for Technology Assessment (ITA) and essentially carries out TA studies mainly for ministries and at EU level, alongside basic research. The communication between the Parliament and the ITA was not very dense for more than ten years. Starting in 2007, contacts between the ITA and the National Assembly (Nationalrat) were intensified; a small enquiry was conducted on the topic of TA and senior ITA members made a number of appearances in the Research, Innovation and Technology Committee. Since 2013 the ITA presents also policy briefs, in the form of ITA dossiers, for parliamentarians and other decision makers in politics and society.

The ITA became a full member of the EPTA in 2013 with the support of the President of the Parliament. The letter of 7 February 2013 from Madame Speaker Barbara Prammer to her Finnish counterpart - at that time Finland held the EPTA Presidency - states inter-alia:

[...] the Parliament is now under way to establish a more regular communication channel that will therefore tie both institutions [i.e. the Parliament and the ITA] together more closely in the future. Austrian Parliamentarians are highly interested in issues regarding the possible impacts of new technologies on our society. We therefore appreciate the work done by ITA and are interested to engage in intensive exchange with ITA staff on issues related to the political and legislative activities of the Austrian Parliament. [...]

The ITA has always played an active role in EPTA and, in 2016, has assumed the EPTA presidency (rotating on an annual basis) for the first time. Since 2015 the ITA is also responsible for all EPTA web activities (homepage, Facebook, news channel).

In 2014, the ITA entered a strategic partnership with the Innovation Systems Department of the Austrian Institute of Technology (AIT), which specialises in foresight studies and technology policy. Together ITA and AIT conducted a feasibility study on the topic of 'Foresight \& TA for the Austrian Parliament' and a first topic-related pilot project (on 'Industry 4.0'). The study resulted in a proposal how to best institutionalise F\&TA in the Parliament (Nentwich et al. 2015), based among other on the systematic comparison of international PTA institutions reported in the present article.

Based on the distinctions of cases and variants found internationally and presented in the sections 2 to 5 above, the main elements of this proposal are summarised in the following Table 3. 
Table 3: A proposal for PTA in Austria

\begin{tabular}{|c|c|c|c|}
\hline Section & Characteristic & $\begin{array}{c}\text { Proposed } \\
\text { cases* }\end{array}$ & Short description of the proposal \\
\hline 2.1 & $\begin{array}{l}\text { Parliamentarians as addressees } \\
\text { or rapporteurs }\end{array}$ & $\mathrm{A} 2$ & $\begin{array}{l}\text { The Parliamentarians would commission } \\
\text { to TA practitioners. }\end{array}$ \\
\hline 2.2 & Entity within parliament or outside & $\mathrm{B} 2$ & $\begin{array}{l}\text { The TA practitioners would work outside } \\
\text { the Parliament. }\end{array}$ \\
\hline 2.3 & Responsibility within parliament & $\mathrm{Cl}$ & $\begin{array}{l}\text { A Board consisting of representatives of } \\
\text { all parties would steer the process. }\end{array}$ \\
\hline 2.4 & $\begin{array}{l}\text { Case-by-case } \\
\text { funding/commissioning or } \\
\text { framework contract }\end{array}$ & $\mathrm{D2}$ & $\begin{array}{l}\text { A framework contract for } 3-5 \text { years would } \\
\text { be concluded with one or more external } \\
\text { institutions. }\end{array}$ \\
\hline 2.5 & $\begin{array}{l}\text { Mission: Focus on parliament or } \\
\text { open contracting structure }\end{array}$ & E2 & $\begin{array}{l}\text { The external contractors would not work } \\
\text { exclusively for Parliament. }\end{array}$ \\
\hline 2.6 & Legal status & $\mathrm{F} 1$ & $\begin{array}{l}\text { The creation would be based on a decision } \\
\text { taken by the Presidential Conference of } \\
\text { the Parliament. }\end{array}$ \\
\hline 3.1 & Identifying topics & $\mathrm{G} 2 / \mathrm{c}$ & $\begin{array}{l}\text { The Board would act as a clearing house } \\
\text { for selecting the TA topics. }\end{array}$ \\
\hline 3.2 & Technology reference & - & $\begin{array}{l}\text { While there would be a strong focus on } \\
\text { technology-related issues, the Board may } \\
\text { also refer broader issues. }\end{array}$ \\
\hline 3.3 & Thematic time horizon & $\mathrm{H} 1 / \mathrm{H} 2$ & $\begin{array}{l}\text { The topics would cover the medium and } \\
\text { long term. }\end{array}$ \\
\hline 4.1 & 'TA secretariat' or 'in-house' TA & 11 & $\begin{array}{l}\text { The TA studies would be carried out in- } \\
\text { house and only occasionally outsourced. }\end{array}$ \\
\hline 4.2. & Methods applied & J1/J2/J3 & $\begin{array}{l}\text { All necessary methods, from expert to } \\
\text { participatory TA and foresight would be } \\
\text { applied. }\end{array}$ \\
\hline 4.3. & Staffing and budget & - & $\begin{array}{l}\text { The proposed annual budget would be } \\
\text { small in a first step [ } 350 \text { TEUR]. }\end{array}$ \\
\hline 5.1 & Written communication & $\begin{array}{l}\mathrm{L} 1 / \mathrm{L} 2 / \mathrm{L} 4 \\
\quad \mathrm{M} 1\end{array}$ & $\begin{array}{l}\text { The TA staff would produce short and long } \\
\text { reports, presentation documents, and } \\
\text { policy briefs with options for actions. }\end{array}$ \\
\hline 5.2. & Oral presentation and discussion & N2/N4 & $\begin{array}{l}\text { The TA staff would organise and present in } \\
\text { the thematically responsible committee or } \\
\text { in special TA events, such as 'breakfast' } \\
\text { meetings. }\end{array}$ \\
\hline
\end{tabular}

* The codes refer to the lists in the sections 2 to 5 of this article.

On 7 October 2016, the Bureau of the Parliament finally decided how to proceed: As a first step, a slender solution will be implemented with a regular monitoring process and a few short studies per year, carried out by external contractors with a three-year framework contract. In winter 2016/2017 the parliamentary administration will issue an invitation to tender. The Institute for Technology Assessment of the Austrian Academy of Sciences will certainly answer the call.

On a final note, the author hopes that not only the Austrian Parliament, but all parliamentary bodies with a competence in technology policy around the world may make use of this systematic and detailed approach to characterize different design options for PTA institutions. Thinking in terms of the multitude of alternatives may help to 'construct' the ideal solution for institutionalizing parliamentary technology assessment - 'ideal' meaning that it fits the political traditions und culture in the respective polity. 


\section{References}

Bröchler, S., Simonis, G. and Sundemann, K. (eds), 1999, Handbuch Technikfolgenabschätzung (3 Bände), Berlin: Edition Sigma.

Decker, M. and Ladikas, M. (eds), 2004, Bridges between Science, Society and Policy. Technology Assessment - Methods and Impacts; in series: Wissenschaftsethik und Technikfolgenbeurteilung, Vol. 22, ed. by Gethmann, C. F., Berlin: Springer Verlag.

Delvenne, P., 2011, Science, technologie et innovation sur le chemin de la réflexivité. Enjeux et dynamiques du Technology Assessment parlementaire; in series: Thélème, Belgique: Academia L'Harmattan, orbi.ulg.ac.be/handle/2268/93695.

Enzing, C., Deuten, J., Rijnders-Nagle, M. and Til, J. v. (Technopolis), 2012, Technology across borders. Exploring perspectives for pan-European Parliamentary Technology Assessment; Study, commissioned by: European Parliament/STOA, No. PE 482.684, March, Brussels: EP, europarl.europa.eu/RegData/etudes/etudes/join/2011/482684/IPOLJOIN_ET\%282011\%29482684_EN.pdf.

Falkner, G., Peissl, W. and Torgersen, H. (eds), 1994, Parlamentarische Technikfolgen-Abschätzung in Europa, e-book: ITA epub.oeaw.ac.at/0xc1aa500e_0x00043020.pdf.

Ganzevles, J., Est, R. v., Brom, F., Adam, F., Attila, Z., Almeida, M., Barland, M., Bütschi, D., Damianova, Z., Delvenne, P., Domínguez, F., Evers, J., Feresin, E., Fixdal, J., Fodor, K., Hebakova, L., Hennen, L., Jacobi, A., Kégler, Á., Leichteris, E., Klüver, L., Kozarev, V., López, B., Nentwich, M., Nierling, L., O’Reilly, P., Folker, M. P., Peissl, W., Rosskamp, B. and Sotoudeh, M., 2012, TA Practices in Europe. Deliverable 2.2 of the PACITA (Parliaments and Civil Society in Technology Assessment) project, commissioned by: European Commission, September: PACITA Consortium, pacitaproject.eu/wp-content/uploads/2013/01/TA-Practices-in-Europe-final.pdf.

Ganzevles, J., van Est, R. and Nentwich, M., 2014, Embracing Variety: Introducing the Inclusive Modelling of (Parliamentary) Technology Assessment, Journal of Responsible Innovation 1(3), 292-313.

Grünwald, R. (ed.), 2012, Parliamentary Technology Assessment in Europe, Berlin: EPTA, oeaw.ac.at/ita/fileadmin/epta/epta-booklet.pdf.

Nentwich, M., Schaper-Rinkel, P., Biegelbauer, P., Fröhlich, J., Gudowsky, N., Peissl, W. and Wasserbacher, D., 2015, Zur Institutionalisierung von Foresight und Technikfolgenabschätzung für das österreichische Parlament; final report, commissioned by: Parlamentsdirektion, No. ITA-AIT-3, November, Vienna: ITA-AIT, epub.oeaw.ac.at/ita/ita-projektberichte/ITA-AIT-3.pdf.

van Est, R., Ganzevles, J. and Nentwich, M., 2015, Modeling Parliamentary Technology Assessment in Relational Terms. Mediating Between the Spheres of Parliament, Government, Science and Technology, and Society, Technikfolgenabschätzung - Theorie und Praxis 24(1), 11-20, tatup-journal.de/english/tatup151_esua15a.php.

Vig, N. J. and Paschen, H. (eds), 2000, Parliaments and Technology, Albany, USA: State University of New York Press. 


\section{Previously published manu:scripts}

ITA-01-01 Gunther Tichy, Walter Peissl (12/2001): Beeinträchtigung der Privatsphäre in der Informationsgesellschaft. $<w w w .0 e a w . a c . a t / i t a / p d f / i t a \_01 \_01 . p d f>$

ITA-01-02 Georg Aichholzer (12/2001): Delphi Austria: An Example of Tailoring Foresight to the Needs of a Small Country. <www.oeaw.ac.at/ita/pdf/ita_01_02.pdf>

ITA-01-03 Helge Torgersen, Jürgen Hampel (12/2001): The Gate-Resonance Model: The Interface of Policy, Media and the Public in Technology Conflicts. <www.oeaw.ac.at/ita/pdf/ita_01_03.pdf>

ITA-02-01 Georg Aichholzer (1/2002): Das ExpertInnen-Delphi: Methodische Grundlagen und Anwendungsfeld „Technology Foresight". <www.oeaw.ac.at/ita/pdf/ita_02_01.pdf>

ITA-02-02 Walter Peissl (1/2002): Surveillance and Security - A Dodgy Relationship. <www.oeaw.ac.at/ita/pdf/ita_02_02.pdf>

ITA-02-03 Gunther Tichy (2/2002): Informationsgesellschaft und flexiblere Arbeitsmärkte. <www.oeaw.ac.at/ita/pdf/ita_02_03.pdf>

ITA-02-04 Andreas Diekmann (6/2002): Diagnose von Fehlerquellen und methodische Qualität in der sozialwissenschaftlichen Forschung. <www.oeaw.ac.at/ita/pdf/ita_02_04.pdf>

ITA-02-05 Gunther Tichy (10/2002): Over-optimism Among Experts in Assessment and Foresight. $<w w w$. oeaw.ac.at/ita/pdf/ita_02_05.pdf>

ITA-02-06 Hilmar Westholm (12/2002): Mit eDemocracy zu deliberativer Politik? Zur Praxis und Anschlussfähigkeit eines neuen Mediums. <www.oeaw.ac.at/ita/pdf/ita_02_06.pdf>

ITA-03-01 Jörg Flecker und Sabine Kirschenhofer (01/2003): IT verleiht Flügel? Aktuelle Tendenzen der räumlichen Verlagerung von Arbeit. <www.oeaw.ac.at/ita/pdf/ita_03_01.pdf>

ITA-03-02 Gunther Tichy (11/2003): Die Risikogesellschaft - Ein vernachlässigtes Konzept in der europäischen Stagnationsdiskussion. <www.oeaw.ac.at/ita/pdf/ita_03_02.pdf>

ITA-03-03 Michael Nentwich (11/2003): Neue Kommunikationstechnologien und Wissenschaft Veränderungspotentiale und Handlungsoptionen auf dem Weg zur Cyber-Wissenschaft. <www.oeaw.ac.at/ita/pdf/ita_03_03.pdf>

ITA-04-01 Gerd Schienstock (1/2004): Finnland auf dem Weg zur Wissensökonomie - Von Pfadabhängigkeit zu Pfadentwicklung. <www.oeaw.ac.at/ita/pdf/ita_04_01.pdf>

ITA-04-02 Gunther Tichy (6/2004): Technikfolgen-Abschätzung: Entscheidungshilfe in einer komplexen Welt. <www.oeaw.ac.at/ita/pdf/ita_04_02.pdf>

ITA-04-03 Johannes M. Bauer (11/2004): Governing the Networks of the Information Society - Prospects and limits of policy in a complex technical system. <www.oeaw.ac.at/ita/pdf/ita_04_03.pdf>

ITA-04-04 Ronald Leenes (12/2004): Local e-Government in the Netherlands: From Ambitious Policy Goals to Harsh Reality. <www.oeaw.ac.at/ita/pdf/ita_04_04.pdf>

ITA-05-01 Andreas Krisch (1/2005): Die Veröffentlichung des Privaten - Mit intelligenten Etiketten vom grundsätzlichen Schutz der Privatsphäre zum Selbstschutz-Prinzip. <www.oeaw.ac.at/ita/pdf/ita_05_01.pdf>

ITA-05-02 Petra Grabner (12/2005): Ein Subsidiaritätstest - Die Errichtung gentechnikfreier Regionen in Österreich zwischen Anspruch und Wirklichkeit. <epub.oeaw.ac.at/ita/ita-manuscript/ita_05_02.pdf>

ITA-05-03 Eva Buchinger (12/2005): Innovationspolitik aus systemtheoretischer Sicht - Ein zyklisches Modell der politischen Steuerung technologischer Innovation. <www.oeaw.ac.at/ita/pdf/ita_05_03.pdf>

ITA-06-01 Michael Latzer (6/2006): Medien- und Telekommunikationspolitik: Unordnung durch Konvergenz - Ordnung durch Mediamatikpolitik. <epub.oeaw.ac.at/ita/ita-manuscript/ita_06_01.pdf>

ITA-06-02 Natascha Just, Michael Latzer, Florian Saurwein (9/2006): Communications Governance: Entscheidungshilfe für die Wahl des Regulierungsarrangements am Beispiel Spam. <epub.oeaw.ac.at/ita/ita-manuscript/ita_06_02.pdf>

ITA-06-03 Veronika Gaube, Helmut Haberl (10/2006): Sozial-ökologische Konzepte, Modelle und Indikatoren nachhaltiger Entwicklung: Trends im Ressourcenverbrauch in Österreich. <epub.oeaw.ac.at/ita/ita-manuscript/ita_06_03.pdf>

ITA-06-04 Maximilian Fochler, Annina Müller (11/2006): Vom Defizit zum Dialog? Zum Verhältnis von Wissenschaft und Öffentlichkeit in der europäischen und österreichischen Forschungspolitik. <epub.oeaw.ac.at/ita/ita-manuscript/ita_06_04.pdf>

ITA-06-05 Holger Floeting (11/2006): Sicherheitstechnologien und neue urbane Sicherheitsregimes. <epub.oeaw.ac.at/ita/ita-manuscript/ita_06_05.pdf>

ITA-06-06 Armin Spök (12/2006): From Farming to „Pharming” - Risks and Policy Challenges of Third Generation GM Crops. <epub.oeaw.ac.at/ita/ita-manuscript/ita_06_06.pdf>

ITA-07-01 Volker Stelzer, Christine Rösch, Konrad Raab (3/2007): Ein integratives Konzept zur Messung von Nachhaltigkeit - das Beispiel Energiegewinnung aus Grünland. <epub.oeaw.ac.at/ita/ita-manuscript/ita_07_01.pdf>

ITA-07-02 Elisabeth Katzlinger (3/2007): Big Brother beim Lernen: Privatsphäre und Datenschutz in Lernplattformen. <epub.oeaw.ac.at/ita/ita-manuscript/ita_07_02.pdf>

ITA-07-03 Astrid Engel, Martina Erlemann (4/2007): Kartierte Risikokonflikte als Instrument reflexiver Wissenspolitik. <epub.oeaw.ac.at/ita/ita-manuscript/ita_07_03.pdf>

ITA-07-04 Peter Parycek (5/2007): Gläserne Bürger - transparenter Staat? Risiken und Reformpotenziale des öffentlichen Sektors in der Wissensgesellschaft. <epub.oeaw.ac.at/ita/ita-manuscript/ita_07_04.pdf>

ITA-07-05 Helge Torgersen (7/2007): Sicherheitsansprüche an neue Technologien - das Beispiel Nanotechnologie. <epub.oeaw.ac.at/ita/ita-manuscript/ita_07_05.pdf>

ITA-07-06 Karen Kastenhofer (9/2007): Zwischen „schwacher“ und „starker“ Interdisziplinarität. Die Notwendigkeit der Balance epistemischer Kulturen in der Sicherheitsforschung zu neuen Technologien.

<epub.oeaw.ac.at/ita/ita-manuscript/ita_07_06.pdf> 
ITA-07-07 Ralf Lindner, Michael Friedewald (9/2007): Gesellschaftliche Herausforderungen durch „intelligente Umgebungen. Dunkle Szenarien als TA-Werkzeug. <epub.oeaw.ac.at/ita/ita-manuscript/ita_07_07.pdf>

ITA-07-08 Alfons Bora (11/2007): Die disziplinären Grundlagen der Wissenschaft. <epub.oeaw.ac.at/ita/ita-manuscript/ita_07_08.pdf>

ITA-08-01 Alexander Degelsegger (5/2008): „Frames“ in sozialwissenschaftlichen Theorieansätzen. Ein Vergleich aus der Perspektive der Technikforschung. <epub.oeaw.ac.at/ita/ita-manuscript/ita_08_01.pdf>

ITA-08-02 Jens Hoff (11/2008): Can The Internet Swing The Vote? Results from a study of the 2007 Danish parliamentary election. <epub.oeaw.ac.at/ita/ita-manuscript/ita_08_02.pdf>

ITA-09-01 Georg Aichholzer, Doris Allhutter (2/2009): e-Participation in Austria: Trends and Public Policies. <epub.oeaw.ac.at/ita/ita-manuscript/ita_09_01.pdf>

ITA-09-02 Michael Nentwich (11/2009): Cyberscience 2.0 oder 1.2? Das Web 2.0 und die Wissenschaft. <epub.oeaw.ac.at/ita/ita-manuscript/ita_09_02.pdf>

ITA-09-03 Hilmar Westholm (12/2009): Wandel der Formen politischer Partizipation und der Beitrag des Internet. Schlussfolgerungen aus Bevölkerungsbefragungen in Deutschland. <epub.oeaw.ac.at/ita/ita-manuscript/ita_09_03.pdf>

ITA-10-01 Iris Eisenberger (12/2010): Kleine Teile, große Wirkung? Nanotechnologieregulierung in der Europäischen Union. <epub.oeaw.ac.at/ita/ita-manuscript/ita_10_01.pdf>

ITA-10-02 Alexander Degelsegger and Helge Torgersen (12/2010): Instructions for being unhappy with PTA. The impact on PTA of Austrian technology policy experts' conceptualisation of the public. <epub.oeaw.ac.at/ita/ita-manuscript/ita_10_02.pdf>

ITA-10-03 Ernest Braun (12/2010): The Changing Role of Technology in Society. <epub.oeaw.ac.at/ita/ita-manuscript/ita_10_03.pdf>

ITA-10-04 Fritz Betz (12/2010): E-Partizipation und die Grenzen der Diskursethik. <epub.oeaw.ac.at/ita/ita-manuscript/ita_10_04.pdf>

ITA-11-01 Peter Parycek, Judith Schoßböck (1/2011): Transparency for Common Good. Offener Zugang zu Information im Kontext gesellschaftlicher und strategischer Spannungsfelder. <epub.oeaw.ac.at/ita/ita-manuscript/ita_11_01.pdf>

ITA-11-02 Georg Aichholzer und Doris Allhutter (6/2011): Online forms of political participation and their impact on democracy. <epub.oeaw.ac.at/ita/ita-manuscript/ita_11_02.pdf>

ITA-11-03 Mahshid Sotoudeh, Walter Peissl, Niklas Gudowsky, Anders Jacobi (12/2011): Long-term planning for sustainable development. CIVISTI method for futures studies with strong participative elements. <epub.oeaw.ac.at/ita/ita-manuscript/ita_11_03.pdf>

ITA-12-01 Xiao Ming (1/2012): e-Participation in Government Decision-Making in China. Reflections on the Experience of Guangdong Province. <epub.oeaw.ac.at/ita/ita-manuscript/ita_12_01.pdf>

ITA-12-02 Stephan Bröchler, Georg Aichholzer, Petra Schaper-Rinkel (Hrsg.) (9/2012): Theorie und Praxis von Technology Governance. <epub.oeaw.ac.at/ita/ita-manuscript/ita_12_02_Sondernummer.pdf>

ITA-12-03 Iris Eisenberger (10/2012): EU-Verhaltenskodex Nanotechnologie: Rechtsstaatliche und demokratische Aspekte. <epub.oeaw.ac.at/ita/ita-manuscript/ita_12_03.pdf>

ITA-12-04 Julia Haslinger, Christiane Hauser, Peter Hocke, Ulrich Fiedeler (10/2012): Ein Teilerfolg der Nanowissenschaften? Eine Inhaltsanalyse zur Nanoberichterstattung in repräsentativen Medien Österreichs, Deutschlands und der Schweiz. <epub.oeaw.ac.at/ita/ita-manuscript/ita_12_04.pdf>

ITA-13-01 Helge Torgersen, Alexander Bogner, Karen Kastenhofer (10/2013): The Power of Framing in Technology Governance: The Case of Biotechnologies. <epub.oeaw.ac.at/ita/ita-manuscript/ita_13_01.pdf>

ITA-13-02 Astrid Mager (11/2013): In search of ideology. Socio-cultural dimensions of Google and alternative search engines. <epub.oeaw.ac.at/ita/ita-manuscript/ita_13_02.pdf>

ITA-13-03 Petra Wächter (12/2013): Aspekte einer nachhaltigen Energiezukunft. <epub.oeaw.ac.at/ita/ita-manuscript/ita_13_03.pdf>

ITA-14-01 Renate Mayntz (8/2014): Technikfolgenabschätzung - Herausforderungen und Grenzen. <epub.oeaw.ac.at/ita/ita-manuscript/ita_14_01.pdf>

ITA-14-02 Michael Narodoslawsky (11/2014): Utilising Bio-resources: Rational Strategies for a Sustainable Bio-economy. <epub.oeaw.ac.at/ita/ita-manuscript/ita_14_02.pdf>

ITA-14-03 Petra Wächter (12/2014): Ökonomik in der Technikfolgenabschätzung - eine Bestandsaufnahme. <epub.oeaw.ac.at/ita/ita-manuscript/ita_14_03.pdf>

ITA-15-01 Reinhard Grünwald (5/2015): Stromnetze: Bedarf, Technik, Folgen. <epub.oeaw.ac.at/ita/ita-manuscript/ita_15_01.pdf>

ITA-15-02 Christine Chaloupka, Robert Kölbl, Wolfgang Loibl, Romain Molitor, Michael Nentwich, Stefanie Peer Ralf Risser, Gerd Sammer, Bettina Schützhofer, Claus Seibt (6/2015): Nachhaltige Mobilität aus sozioökonomischer Perspektive - Diskussionspapier der Arbeitsgruppe „Sozioökonomische Aspekte“ der ÖAW-Kommission „Nachhaltige Mobilität“. <epub.oeaw.ac.at/ita/ita-manuscript/ita_15_02.pdf>

ITA-15-03 Sabine Pfeiffer (10/2015): Auswirkungen von Industrie 4.0 auf Aus- und Weiterbildung. <epub.oeaw.ac.at/ita/ita-manuscript/ita_15_03.pdf>

ITA-15-04 Sabine Pfeiffer (11/2015): Effects of Industry 4.0 on vocational education and training <epub.oeaw.ac.at/ita/ita-manuscript/ita_15_04.pdf>

ITA-16-01 Lorenzo Del Savio, Alena Buyx \& Barbara Prainsack (3/2016): Opening the black box of participation in medicine and healthcare. <epub.oeaw.ac.at/ita/ita-manuscript/ita_16_01.pdf>

ITA-16-02 Michael Nentwich (10/2016): Parliamentary Technology Assessment Institutions and Practices. <epub.oeaw.ac.at/ita/ita-manuscript/ita_16_02.pdf> 